\title{
New Media Art Design Combined with Art and Digital Technology
}

\author{
Hong Li \\ Department of Art, Science and Technology College Gannan Normal University, Ganzhou 341000, China \\ lihonggn@126.com
}

Keywords: modern art; digital technology; new media art design; information dissemination; media digital technology

\begin{abstract}
Since the birth of the new media art design, it has been widely concerned by the people in the industry. Today, when the Internet technology is highly developed, the combination of traditional art design form and digital technology is the great innovation and inevitable result of art design development. The new media art design brings people different artistic experience, which can encourage people to feel, hear and even touch the beauty of art from the aspects of vision, enrich human spiritual life and improve people's quality of life and other aspects of work.
\end{abstract}

\section{Introduction}

With the development of science and technology, the combination of modern art and digital technology gives birth to a new art form, that is, new media art. Based on the integration of modern art and digital technology, great changes have taken place in the artistic attainments, design styles and forms of expression of new media art. This paper analyzes the problems existing in the actual development of new media art and discusses how to train new media art talents because of the combination of modern art and digital technology. The aim is to provide reference for the healthy and sustainable development of modern new media art in China. Since the beginning of the 21st century, the rapid development of Internet technology has also promoted the change of traditional media art. Nowadays, media art design is more and more closely related to digital technology, which gives rise to a new form of art design, which called new media art design. The new media art design started late in our country, although it has obtained certain achievement, obtained the higher attention degree, but also has some drawbacks. How to solve these problems and make the new media art of design industry flourish is a serious problem that the majority of new media artists need to consider.

In the eighties of the 20th century, the new media art rose gradually in our country, and has become an indispensable part of the modern art in our country in the long-term development process, especially in the art circle; the new media art is the hot spot and the focus of attention. The Development of New Media Art

It is an important form of art in which modern science and technology into the field of art. New media art is the demand of modern art and modern society for the development of art; so many fields have gradually penetrated into new media art, which has brought new vitality to the development of art.

\section{Great Advantages of New Media Art Design}

The cost of access to information by the audience is lower

The product information of traditional media art design transmitted to the general audience through newspapers, magazines and other media, but the process of the public understanding of new media art of design products is relatively simple. As long as it connected to the Internet by means of a mobile phone or a computer, etc.

It can easily access all kinds of information of new media art of design products, its process is quick and simple, and the cost is extremely low. The amount of information on art and design of media that the public understands through the Internet at the same time is much larger than that 
obtained through forms such as print media, and because the Internet is popular with young people, So new media art design is also easier to get a larger audience than traditional media design.

\section{Highly Interactive New Media Art}

The traditional media art is not satisfactory in the interactive link with the audience, but the new media art design based on digital technology is different, because the new media art depends on the Internet to design, therefore, it often produces very good interaction with the audience. People can easily appreciate design works through devices such as computers or mobile phones, which is difficult for the traditional media design industry to do. The traditional media art design work from putting forward the concept of design to get the final product into the public vision often needs to go through many links, and need to spend more time. Today, when the rhythm of life is very tight, the traditional media art design is obvious. However, it has been unable to meet the requirements of the times.

\section{Analysis on the Present Situation of New Media Art Design Industry in China}

Lack of High quality talents in New Media Art Design

New media art design is, by definition, a combination of new media and art design, and the new media here mainly refers to the Internet. Therefore, the practitioners of new media art design should have sufficient professional knowledge and computer operation experience. However, it is regrettable that the domestic new media art of design industry is facing the situation of high quality and complex talent shortage, and few of the existing designers can fully meet the requirements of new media art design. This has become the domestic new media art of design industry development of one of the short board.

\subsection{Lack of correct understanding of New Media Art Design in industry}

New media art design has been around in China for some time. During this period, the public has seen the development of new media art design and people in the industry are proud of it. However, at present, what is more disappointing is the lack of a correct understanding of the work of new media art design in the field of domestic media art design. Most people still look at the development of the new media art of design industry from the perspective and standards of looking at the traditional media. To some extent, it has a negative impact on the progress of the new media art of design industry, which is not conducive to the improvement and progress of the new media art of design technology.

\subsection{Imperfect industry related system}

As a new concept, the development time of new media art design is far less than that of traditional media design. Therefore, the new media art of design industry needs every system to ensure its normal operation order. What backfires is that the Chinese government has inadequate supervision over the new media art of design industry, and the relevant policies and systems in the industry are relatively imperfect. This makes the industry prone to some undesirable design products such as junk web pages. In turn, the industry has a bad impact.

\section{Problems in the Development of New Media Art Design}

Insufficient understanding of discipline Construction

Digital technology has been widely used in the field of art. The concrete application of digital technology is the support and assistance of computer network technology to art design. For example, animation designs, electronic competitive game design, media art design and so on. Secondly, digital technology also plays a vital role in advertising, and news and other industries, which mainly promote the innovation of advertising and news media and values, catch the eyes of the public, and meet the aesthetic needs of people. New media art is a new art subject based on the combination of 
modern art and digital technology. With the development of new media art, the lag of traditional art forms is more prominent, which cannot meet the needs of art in the society of information age.

\subsection{Talent training problem}

New media art is a new kind of art subject under the background of information age, which has the characteristics of compounding and interdisciplinary. In the aspect of training talents, it is necessary to master the students' modern artistic accomplishment and the law of art subject design. Train the design method of student computer graphics; provide more modern art talents for the modern society market. Digital technology talents and new media art talents are the much-needed talents in the field of modern art design, but in the process of cultivating this type of art talents, it is easy to break away from them. Market law phenomenon, must strictly in accordance with the social market demand for talent to formulate goals and plans.

\subsection{Cultivation object problem}

Higher education is becoming more and more popular in our country, and the number of students choosing art subject is increasing year by year. However, there are some differences in the skill and skill level of the art students, which results in the conflict between the students' artistic specialty and the development of the comprehensive quality, and the level of the art literacy runs counter to the actual requirements of the subject. In this case, the development of new media art in professional art education is very difficult.

\subsection{Measures of cultivating New Media Art talents on the basis of the combination of Modern Art and Digital Technology}

By exploring the problems existing in the development of the new media art subject and combining the specific requirements of the modern social market for the new media art design talents, we can perfect the training mechanism of the new media design art talents through the following measures. First, in the art colleges, we should pay attention to the communication and exchange among different disciplines, share resources, fully draw lessons from the technical advantages of different disciplines, and apply them to the training of talents in this discipline. Construct the media art teaching system with complementary advantages. Then, because of sharing resources and complementing each other's advantages, a systematic and standardized teaching platform constructed to enable all art disciplines to enough to obtain effective teaching resources on the teaching platform. To achieve the cultivation of students' art design ability and basic design skills, and gradually realize the training goals and plans of new media art design talents. Second, it is necessary to combine the specific requirements of the social market and the content of the practice of modern digital technology, constantly the new media art-teaching model, uphold the artistic purpose of "take its essence and discard its dregs". This paper inherits the positive factors in traditional art education and combines these factors with modern digital art to construct a new model of new media art education. New media art design is a professional with high requirements for operation and practicality. Art colleges and universities should create a teaching environment suitable for the development of new media art, and set up related art supporting facilities. Let the student's knowledge theory and operation practice combine, improve the level of student's art design continuously. Thirdly, because of cultivating students' artistic skills, we should pay attention to cultivating students' creative ability and practical operation ability, to ensure that students' artistic design skills adapt to the new media era. Secondly, it is necessary to strengthen the construction of teachers and the quality of art education. Especially in the context of the new media era, the development of new media art should combine. The advantages of the social market solve the problems existing in the training mechanism of the new media art talents and take the market as the guide to cultivate the new media art talents who can meet the needs of the social development. Throughout the development of human civilization, science, technology, and art developed in a mutually reinforcing way. Digital technology stimulates artistic innovation, deeply changes the form of art design, and promotes the development of new media art. It plays a vital role in enriching the content and emotion of modern art. Therefore, new media art design should in the talent training 
colleges; we should establish the teaching system of the exchange and the sharing of the resources among the subjects and the complementary advantages of the subjects.

\section{Government departments should strengthen the supervision of the new media art of design industry}

New media art design not only brings people rich information, but also brings some challenges to the regulators because of its own special features. so in the information explosion today is bound to bring people some bad information. In order to avoid the above situation, the relevant regulatory authorities should strengthen the supervision of the industry, improve the various systems, and resolutely punish those who undermine the order of the development of the industry, to curb the dissemination of bad information. To ensure the cleanliness of the network in order to win the trust and support of the new media art design industry.

\section{Summary}

New media art design has made great progress by virtue of its own huge advantages, and has made outstanding contributions to accelerating the progress of media design industry and enriching the spiritual and cultural life of the people in our country. Therefore, the relevant parties should take effective measures to solve the problems existing in the field of art design of new media in China at present, to ensure the steady and healthy development of the art design industry of new media. For the future and development prospects of new media art design, the relationship between science and technology and art has always been mutually promoted and assisted in the development of human civilization at all stages of history. However, few references have made such as the current digital technology and network communication technology. It can say that in modern life, new media art has substantially reformed the thinking mode of art, design patterns, communication patterns and appreciation patterns. New media art is becoming an indispensable part of life in the new century, and people can help to express their inner art by helping the rich form of this platform. The art design of new media is a new subject, which combines the development of digital science and technology and art. It is the product of social development and the spread of digital information is more thorough and comprehensive with the development of society and science and technology. The training and education of digital art talents will face a great development. Space, we should conform to the development of the times, seize the opportunity to open up a brilliant new media art.

\section{References}

[1] Liu C eng. A study on the influence of Digital Technology on the Art of New Media [J]. Literature and Art Life Theory of Literature and Art 2014

[2] Cui W j. A study on the influence of Digital Technology on the Art of New Media [D]. Harbin normal University 2013

[3] Zhao S w. The change and influence of the Development of Modern Digital Technology on the Art of New Media [J]. Electronic Journal of the New Educational Age (teacher Edition / 2015)

[4] Ni M t. Computer Graphics [M]. Beijing: Peking University, Sichuan Office, 2005.

[5] China Council of Digital Media Arts and Design, Apple computer International Co., Ltd. Art Education in Digital Media [M]. Beijing: ocean Publishing House 2002: 10.

[6] Zhang Y x. New Media Art [M]. Beijing: S z Fine Arts Press, China.

[7] Wang received it. History of Modern Design in the World [M]. Beijing: China Youth Press 2002: 24-29.

[8] Liu F q. Multimedia Image Technology and Application [M]. Beijing: people's Post and Telecommunications Press.

[9] R Bin. On the Art of Digital Media [J]. Journal of Northwestern University: philosophy and Social Sciences Edition 2004 / 5: color pages. 